\title{
Preliminary study on potential mechanical vectors of animal trypanosomes in the Far North region of Cameroon
}

\author{
Pierre Fongho Suh ${ }^{1,2^{*}}$ Flobert Njiokou ${ }^{1}$ Rebecca Garabed ${ }^{3}$ \\ Abdoulmoumini Mamoudou ${ }^{4}$ Mouhaman Arabi $^{5}$ \\ Ahmadou Tidjani Malam ${ }^{6}$
}

\section{Keywords}

Cattle, Atylotus agrestis, Tabanidae, African trypanosomiasis, vectors, Cameroon

Submitted: 25 April 2019

Accepted: 2 July 2019

Published: 30 September 2019

DOI: $10.19182 /$ remvt.31782

\section{Summary}

An entomological study was carried out in the Far North region of Cameroon historically known focus for animal trypanosomosis and declared tsetse free in the late $1970 \mathrm{~s}$ - to determine the potential mechanical vectors for trypanosomes and their spatial preference in this region. Thirty-one Nzi traps were installed at 6:30-8:00 a.m. in Goulfey, Madiako canton and Darack karena in Logone and Chari Division, as well as in Guidiguis, Kalfou and Maga-Guirvidig in two other divisions. They were visited after 10-11 hours of exposition. The sampling lasted one day. A total of 20,084 hematophagous flies (865 Stomoxys and 19,219 tabanids) were collected. Stomoxys niger was the only Stomoxyinae species caught, whereas five species of tabanids were collected: Atylotus agrestis, A. albipalpus, A. fuscipes, Tabanus taeniola and T. biguttatus. A. agrestis was by far the most prevalent species $(92.7 \%)$, followed by $T$. taeniola (7.1\%). The apparent densities of 50.1, 409.4 and 1499.0 tabanids per trap per day in Guidiguis, Goulfey and Madiako canton, respectively, were significantly different $(p=0.0002)$. Tabanids were more abundant in campsites than in pastures and water points. Atylotus agrestis seemed to be the major potential mechanical vector of trypanosomes in the area.

- How to quote this article: Suh P.F., Njiokou F., Garabed R., Mamoudou A., Arabi M., Malam A.T., 2019. Preliminary study on potential mechanical vectors of animal trypanosomes in the Far North region of Cameroon. Rev. Elev. Med. Vet. Pays Trop., 72 (3): 133-136, doi: 10.19182/remvt.31782

\section{INTRODUCTION}

The Far North region of Cameroon is a Sudano-Sahelian zone and one of the most important for animal husbandry in Lake Chad Basin, with a cattle population estimated at 2.1 million and a small stock population estimated at 2.8 million (Ziébé et al., 2005). Disease surveillance in this region covering over 34,000 square kilometers is

\footnotetext{
1. Department of Animal Biology and Physiology, Faculty of Science, University of Yaounde I, PO BOX 812, Yaounde, Cameroon.

2. Saint-Jerome School of Health Sciences, Saint-Jerome Catholic University, Institute of Douala, Douala, Cameroon.

3. Department of Veterinary Preventive Medicine, College of Veterinary Medicine, Ohio State University, USA.

4. Department of Parasitology and Parasitological Diseases, School of Veterinary Medicine and Science, University of Ngaoundere, Cameroon.

5. The Higher Institute of the Sahel, University of Maroua, Cameroon.

6. Mission spéciale d'éradication des glossines, Adamawa Region, Cameroon.

* Corresponding author

Tel.: +237 $675327946 ; 655469698$

Email: fongho_pierre@yahoo.fr; pfongho@univ-catho-sjd.com
}

however poor because of the financial and infrastructural limitations of its 145 zootechnical and veterinary centers (field offices for the Ministry of Livestock, Fisheries and Animal husbandry or MINEPIA). Under these conditions, health issues may occur in livestock and remain unnoticed for years.

A recent parasitological survey implemented following disease reporting by pastoralists revealed the presence of trypanosomosis nearly four decades after the last case was reported (Suh et al., 2017). The biological vector of trypanosomes is the tsetse fly. The elimination of this insect was achieved in this area in the early 1970s, after a series of successful vector control campaigns. The occurrence of animal trypanosomosis in the complete absence of the biological vector has already been reported in other African countries and even out of the continent (Delafosse et al., 2006; Jones and Dávila, 2001). To explain this situation, mechanical transmission of animal trypanosomes by other hematophagous flies was shown as a means to disease maintenance (Desquesnes and Dia, 2003a; 2003b). It occurs when trypanosome-contaminated blood residues present on insect mouthparts are introduced into a naïve host immediately after the insect blood meal on an infected host is interrupted (Baldacchino et al., 2014). The main factor relative to the biting insects facilitating the occurrence of this 
phenomenon is vector density (Oldroyd, 1954). Tabanids belonging to Tabanus, Atylotus and Ancala genera are deemed, by the size of their mouthparts and feeding behavior, better mechanical vectors than Stomoxys flies (Oldroyd, 1954; Zumpt, 1973). Species of these genera have already been described in the Far North region of Cameroon, and the distribution map of the many species of tabanids of Cameroon has been elaborated (Ovazza et al., 1970), but the data displayed has been limited to the presence or absence of information on the species.

The present survey carried out several decades after the biological vector was eliminated in the Far North is a preliminary entomological investigation that aimed at determining the potential mechanical vectors of animal trypanosomes in two historically tsetse-infested areas, as well as their relative importance and distribution.

\section{MATERIALS AND METHODS}

\section{Study area}

The historical tsetse-infested foci retained for this study were Goulfey and Madiako canton, respectively located northward and southward to Kosseri, chief town of Logone and Chari Division. Four other sites, Guidiguis, Kalfou, Darack karena and Maga-Guirvidig, were included in the survey (Figure 1). Darack karena is also in Logone and Chari and close to Lake Chad. Guidiguis and Kalfou are in Mayo Kani and Mayo Danay divisions, respectively. They are agropastoral localities. Maga-Guirvidig, also inMayo Danay, is near Lake Maga, which is part of the floodplain whose seasonal resources, fodder and water, help livestock overcome the particularly difficult dry season. The mean annual temperature of the Far North is $28^{\circ} \mathrm{C}$; the highest temperature is $40^{\circ} \mathrm{C}$ recorded during the hot and dry season (MarchApril); the lowest temperature is $17.1^{\circ} \mathrm{C}$ in the cold and dry season (December-January).

\section{Trap deployment and vector sampling}

Thirty-one Nzi traps were deployed in November 2013 in the study area: Goulfey (8), Madiako canton (9), Guidiguis (6), Kalfou (3), Maga-Guirvidig (2) and Darack karena (3). Traps were installed in

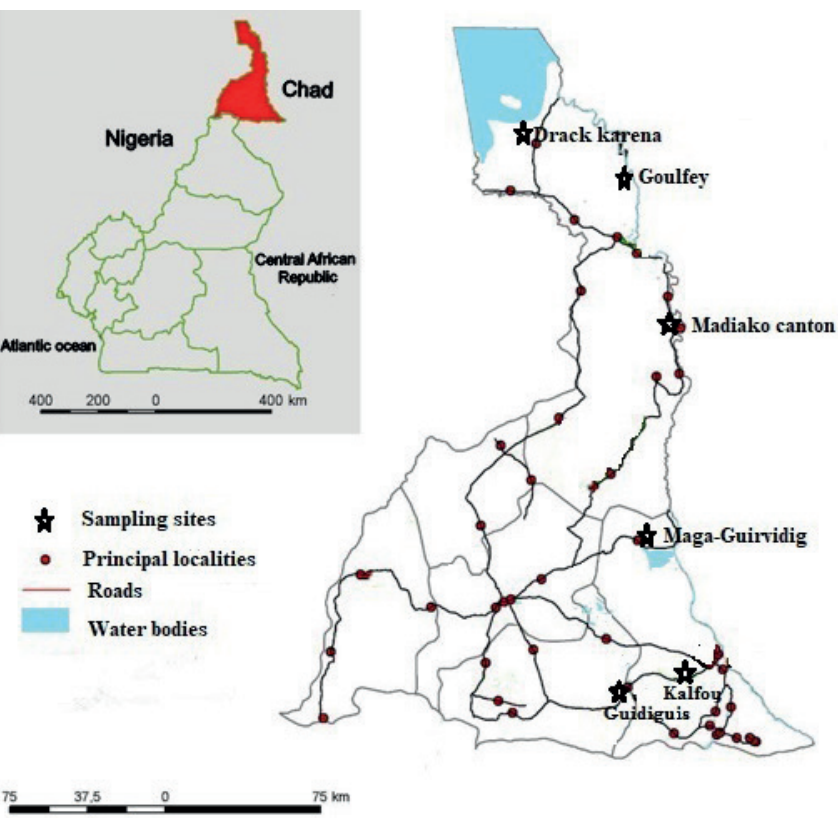

Figure 1: The Far North region of Cameroon showing sampling sites. the morning (6:30-8:00) around i) campsites, ii) grazing areas, and iii) water points. These three biotopes were sampled in Goulfey, Madiako canton, Guidiguis and Kalfou, campsite and water points in Maga-Guirvidig, and water points only in Darack karena. Traps were set 100 meters minimum from one another and georeferenced. After 10-11 hours of exposition, flies caught were collected and conserved (specimens were dried then sealed in tubes containing silica gel) for identification. Sampling was carried out in one day in each site.

\section{Vector identification and abundance evaluation}

Trapped insects were brought to the field laboratory and sorted according to their family. Specimens were examined under binocular magnifying glasses. Identification keys from Oldroyd (1954) were used to separate tabanid species and other keys from Zumpt (1973) to identify Stomoxys. Some specimens were dried and conserved for further examination. Data were recorded in Excel spreadsheets and the apparent density per trap (ADT), expressing the relative abundance of vectors at each trapping site, was calculated with the formula $\mathrm{ADT}=\mathrm{C} / \mathrm{TD}$, where $\mathrm{C}$ is the number of vectors caught, $\mathrm{T}$ the number of traps deployed and $\mathrm{D}$ the number of days of trapping. The distribution of data was tested for normality with Shapiro Wilks test; chi-square and $\mathrm{Z}$ tests were used to compare species prevalence, and Kruskal-Wallis test for ADT comparison. Only Goulfey, Guidiguis and Madiako canton were compared for ADT. Other villages were excluded because the number of traps used could not evaluate ADT correctly. All statistical tests were performed with XLSTAT 2017 Data Analysis and Statistical Solution for Microsoft Excel, Addinsoft, France (2017).

\section{RESULTS AND DISCUSSION}

Hematophagous insects trapped in the zone belonged to Tabanidae and Muscidae. These two families of Diptera have also been reported in neighboring countries, in Chad and Nigeria (Ahmed et al., 2006; Doutoum et al., 2002), where species of the superfamily Hippoboscoidea, including Glossinidae, were also caught. During the present study, no tsetse fly was captured. This preliminary study could not, of course, confirm with certainty the absence of these families. However, the absence of tsetse flies (Glossinidae) in Goulfey and Madiako canton is consistent with findings obtained in 1968 in the same sites after a series of tsetse eradication campaigns (Gruvel et al., 1970).

Stomoxys niger, a species of the Stomoxyinae subfamily well adapted to African savanna and forest, was the only observed hematophagous representative of the Muscidae. A total of 865 specimens of this species were sampled. The absence of S. calcitrans, reported several decades ago in neighboring Diamare Division, suggests that these two species are either geographically separated or that their distribution is influenced by seasons (Mouchet and Rageau, 1962). The use of other traps such as Vavoua as well as the addition of attractants like ammonia and phenylpropanoid compounds could improve sampling and better describe the diversity of Stomoxyinae, and finally give strong evidence of the geographical distribution of these two species (Gibson and Torr, 1999).

With 19,219 specimens collected, tabanids were by far the most captured insects. Dia et al. (2004) made a similar observation in Lahirasso, Burkina Faso, using the same trap. We identified five species belonging to Atylotus (92.9\%) and Tabanus (7.1\%) genera: Atylotus agrestis (17,810), A. albipalpus (49), A. fuscipes (3), Tabanus taeniola (1355), and T. biguttatus (2). Species diversity was three times lower than observations made four decades earlier (Ovazza et al., 1970). The difference may partly be attributable to the seasonality of some species and/or the sampling method (Desquesnes et al., 2005). The very high dominance of Atylotus agrestis, already observed in the 
Far North (Cuisance, 1996) and reported in other countries among which Chad (Doutoum et al., 2002), confirms firstly that this species is remarkably well adapted to savanna zones (Oldroyd, 1954) and secondly that it is the major potential mechanical vector of animal trypanosomes in the region. Desquesnes and Dia (2003a; 2003b) also showed that A. agrestis and A.fuscipes were efficient mechanical vectors for T. vivax and T. congolense.

Tabanus taeniola, the second most abundant species, was described in both savanna and forest zones (Oldroyd, 1954), and previously observed in Logone and Chari (Ovazza et al., 1970). T. biguttatus, like A. agrestis, is a species that prefers the savanna zone of Africa (Oldroyd, 1954). It represented, however, only $0.01 \%$ of all tabanids trapped, a value ten times lower than that obtained in Chad (Doutoum et al., 2002). This species being less likely to enter a trap if the entry is low as in the Nzi trap (Mihok, pers. commun.) might explain its very low prevalence, concomitantly to the effect of seasons on its distribution. A third species of Tabanus, i.e. T. gratus, was intercepted during its flight in Goulfey but was not found in the trap captures.

The lowest catch of $S$. niger was 0 and the highest 560. The apparent densities were 4.7 (SD = 5.6), 6.3 (12.6) and 90.0 (192.3) in Guidiguis, Madiako canton and Goulfey, respectively, but, contrary to the ADT of tabanids, the differences in ADT were not significant $(\mathrm{K}=5.871$; df:2; $p=0.053$ ). For tabanids, the ADT were 50.1, 409.4 and 1499.0 in Guidiguis, Goulfey and Madiako canton, respectively, and were significantly different $(K=16.241$; $d f=2, p=0.0002)$. The densities of tabanids only varied according to the biotope, and the highest were recorded around campsites followed by pastures and water points (Table I). The observed difference reflects the existence of a spatial preference resulting probably from the attraction these insects have to volatile compounds released by animal feces and urine present abundantly in this biotope and indicative for host position (Baldacchino et al., 2014) or simply a dry season behavior pattern. Tabanids are known to be sensitive to meteorological variations. During the dry season, they seem to limit their activities to early morning and late afternoon as an avoidance response to hot periods of the day (Raymond, 1989; Desquesnes et al., 2005). These periods coincide with cattle returns from pastures to campsites at the end of the day, or with the moment preceding their departure from campsites to grazing. In Madiako canton, the densities recorded were particularly high compared to other pastoral villages. Apart from the floodplain, the rarity of water points during the dry season could influence the

\section{REFERENCES}

Ahmed A., Okiwelu S., Samdi S., 2006. Species diversity, abundance and seasonal occurrence of some biting flies in Southern Kaduna, Nigeria. Afr. J. Biomed. Res., 8 (2): doi: 10.4314/ajbr.v8i2.35770

Baldacchino F., Desquesnes M., Mihok S., Foil L.D., Duvallet G., Jittapalapong S., 2014. Tabanids: Neglected subjects of research, but important vectors of disease agents! Infec. Genet. Evol., 28: 596-615, doi: 10.1016/j.meegid.2014.03.029

Cuisance D., 1996. Réactualisation de la situation des tsé-tsé et des trypanosomoses animales au Tchad. Phase II Zone du Lac, Guera, Salamat. Enquête réalisée du 22 mars au 20 avril 1996. http://agritrop. cirad.fr/327260/ (consulté 23 avr. 2019)

Delafosse A., Thébaud E., Desquesnes M., Michaux Y., 2006. Epidemiology of Trypanosoma vivax infection in cattle in the tse-tse free area of Lake Chad. Prev. Vet. Med., 74 (2-3): 108-119, doi: 10.1016/j. prevetmed.2005.10.006

Desquesnes M., Dia M.L., 2003a. Trypanosoma vivax: mechanical transmission in cattle by one of the most common African tabanids, Atylotus agrestis. Exp. Parasitol., 103 (1-2): 35-43, doi: 10.1016/S00144894(03)00067-5 development of tabanids and their abundance (Desquesnes et al., 2005; Suh et al., 2015).

In conclusion, of all the hematophagous insects sampled, Atylotus agrestis was by far the most abundant potential vector of animal trypanosomes in the study area, and probably the major contributor to the resurgence of trypanosomosis decades after the biological vector was eliminated. Its abundance was highest in the pastoral area of the floodplain, probably because of the availability of water resources. Moreover, tabanids seemed to have a spatial preference for campsites. More studies that include other areas and are carried out in both rainy and dry seasons are necessary to describe the existing species richness.

\section{Acknowledgments}

This study was supported by the National Science Foundation through a grant (DEB-1) to the Disease Ecology and Computer Modeling Laboratory (DECML) at Ohio State University (USA). The authors thank the Centre d'Appui à la Recherche et au Pastoralisme (CARPA) team for technical assistance and the Regional delegation of MINEPIA for their administrative support.

\section{Author contributions statement}

FN, MA and RG: study design, planning and critical review of the manuscript; PFS: data collection, data analysis, and interpretation and writing of the first version of the manuscript; ATM: data collection; MA: critical review of the manuscript.

\section{Table I}

Apparent density of Tabanidae according to the biotopes in Far North Cameroon

\begin{tabular}{llcc} 
& \multicolumn{3}{c}{ Apparent density of Tabanidae } \\
\cline { 2 - 4 } Biotope & Atylotus (n) & Tabanus (n) & All tabanids (n) \\
Water point & $189.6(2,275)$ & $21.8(261)$ & $211.3(2,536)$ \\
Campsite & $991.8(11,902)$ & $81.2(974)$ & $1073.0(12,876)$ \\
Pasture & $526.4(3,685)$ & $17.4(122)$ & $543.6(3,805)$ \\
K (p) & $9.038(0.011)$ & $5.855(0.054)$ & $9.106(0.011)$
\end{tabular}

$\mathrm{n}$ : number of specimens trapped; K: Kruskal-Wallis value; p: level of significance

Desquesnes M., Dia M.L., 2003b. Mechanical transmission of Trypanosoma congolense in cattle by the African tabanid Atylotus agrestis. Exp. Parasitol., 105 (3-4): 226-231, doi: 10.1016/j.exppara.2003.12.014

Desquesnes M., Dia M.L., Acapovi G., Yoni W., Foil L., Pin R., 2005. Les vecteurs mécaniques des trypanosomoses animales: généralités, morphologie, biologie, impacts et contrôle. Identification des espèces les plus abondantes en Afrique de I'Ouest. http://agritrop.cirad.fr/534222/ (consulté 23 avr. 2019)

Dia M.L., Desquesnes M., Elsen P., Lancelot R., Acapovi G., 2004. Evaluation of new trap for tabanids and stomoxyines. Bull. Soc. Roy. Belge Entomol., 140: 64-73

Doutoum Abdesalam A., Delafosse A., Elsen P., Amsler Delafosse S., 2002 Potential vectors of Trypanosoma evansi in camels in Eastern Chad. Rev. Elev. Med. Vet. Pays Trop., 55 (1): 21-30, doi: 10.19182/remvt.9841

Gibson G., Torr S.J., 1999. Visual and olfactory responses of haematophagous Diptera to host stimuli. Med. Vet. Entomol., 13 (1): 2-23, doi 10.1046/j.1365-2915.1999.00163.x

Gruvel J., Fernagut R., Siméon M., 1970. Execution of an inunterrupted campaign of tsetse flies eradication by insecticide spraying in the MayoKebbi and Benoue valleys of Cameroon. Rev. Elev. Med. Vet. Pays Trop., 23 (1): 93-99, doi: 10.19182/remvt.7713 
Jones T.W., Dávila A.M.R., 2001. Trypanosoma vivax - out of Africa. Trends Parasitol., 17 (2): 99-101, doi: 10.1016/S1471-4922(00)01777-3

Mouchet J., Rageau J., 1962. Arthropodes d'intérêt médical du Diamaré Rech. Etudes Cameroun, 3 (9) : 73-108

Oldroyd H., 1954. The horse-flies (Diptera: Tabanidae) of the Ethiopian region. II. Tabanus and related genera. British Museum, London, UK, $338 \mathrm{p}$.

Ovazza M., Mouchet J., Rickenbach A., 1970. Tabanidae du Cameroun II. Les espèces connues et leur répartition. Cah. Orstom, Sér. Ent. Méd. Parasitol., 8 (4): 323-351

Raymond H.L., 1989. Distribution temporelle des principales espèces de taons (Diptera Tabanidae) nuisibles au bétail en Guyane française. Ann. Soc. Entomol. Fr., 25 : 289-294
Suh P.F., Njiokou F., Mamoudou A., Ahmadou T.M., Mouhaman A., Garabed R., 2017. Bovine trypanosomiasis in tsetse-free pastoral zone of the FarNorth region, Cameroon. J. Vector Borne. Dis., 54 (3): 263-269, doi: 10.4103/0972-9062.217618

Suh S.J., Kim H.C., Chong S.T., Kim M.S., Klein T.A., 2015. Seasonal abundance of deer and horse flies (Diptera: Tabanidae) in the Northern Part of Gyeonggi-do, Republic of Korea. Korean. J. Parasitol., 53 (3): 307-314, doi: 10.3347/kjp.2015.53.3.307

Ziébé R., Thys E., De Deken R., 2005. Analysis of livestock production systems at the subdistrict level. Case of Bobovo in Far-North Cameroon. Rev. Elev. Med. Vet. Pays Trop., 58 (3): 159-165, doi: 10.19182/remvt.9928

Zumpt F., 1973. The Stomoxyine biting flies of the world. Diptera: Muscidae. Taxonomy, biology, economic importance and control measures. Gustav Fischer Verlag, Stuttgart, $175 \mathrm{p}$.

\section{Résumé}

Suh P.F., Njiokou F., Garabed R., Mamoudou A., Arabi M. Malam A.T. Etude préliminaire sur les vecteurs mécaniques potentiels des trypanosomes animaux dans la région de l'Extrême-Nord du Cameroun

Une étude entomologique a été menée dans la région de I'Extrême-Nord du Cameroun - foyer historiquement connu pour la trypanosomose animale et déclaré exempt de glossines à la fin des années 1970 - afin de déterminer les vecteurs mécaniques potentiels des trypanosomes et leur préférence spatiale dans cette région. Trente et un pièges Nzi ont été installés le matin ( 6 h $30-8$ h 00) à Goulfey, Madiako canton, Darack Karena dans le département de Logone et Chari, ainsi qu'à Guidiguis, Kalfou et Maga-Guirvidig dans deux autres départements. Ils ont été inspectés après 10 à 11 heures d'exposition. L'échantillonnage a duré un jour. Au total 20084 mouches hématophages (865 Stomoxys et 19219 tabanidés) ont été récoltées. Stomoxys niger a été la seule espèce de Stomoxyinae capturée, alors que cinq espèces de tabanidés ont été relevées: Atylotus agrestis, A. albipalpus, A. fuscipes, Tabanus taeniola et T. biguttatus. A. agrestis était de loin I'espèce la plus répandue $(92,7 \%)$, suivie de $T$. taeniola $(7,1 \%)$. Les densités apparentes de 50,1, 409,4 et 1499,0 tabanidés par piège et par jour, respectivement à Guidiguis, Goulfey et Madiako, étaient significativement différentes ( $p=$ 0,0002). Les tabanidés étaient plus abondants dans les campements que dans les pâturages et les points d'eau. Atylotus agrestis a semblé être le principal vecteur mécanique potentiel des trypanosomes dans la région.

Mots-clés : bovin, Atylotus agrestis, Tabanidae, trypanosomose africaine, vecteur de maladie, Cameroun

\section{Resumen}

Suh P.F., Njiokou F., Garabed R., Mamoudou A., Arabi M., Malam A.T. Estudio preliminar sobre posibles vectores mecánicos de tripanosomas animales en la región del Extremo-Norte de Camerún

Se realizó un estudio entomológico en la región del Extremo-Norte de Camerún - zona conocida históricamente por la tripanosomosis animal y declarado libre de la mosca tsé-tsé a fines de la década de 1970 - con el objetivo de determinar los posibles vectores mecánicos de los tripanosomas y sus preferencias espaciales en esta región. Treinta y una trampas Nzi fueron instaladas en horas de la mañana (06:30-08:00) en Goulfey, en el cantón Madiako, Darack Karena, en el departamento de Logone y Chari, y en Guidiguis, Kalfou y Maga-Guirvidig en otros dos departamentos. Después de un espacio de 10 a 11 horas de exposición, dichas trampas fueron inspeccionadas. El muestreo duró un día. Se recogieron en total 20084 moscas hematófagas (865 Stomoxys y 19219 tabánidos). Stomoxys niger fue la única especie de Stomoxyinae capturada, mientras que en el caso de los tabánidos se registraron cinco especies: Atylotus agrestis, A. albipalpus, A. fuscipes, Tabanus taeniola y T. biguttatus. A. agrestis fue ampliamente la especie más expandida $(92,7 \%)$, seguida de la $T$. taeniola $(7,1 \%)$. Las densidades aparentes fueron significativamente diferentes ( $p=0,0002)$ entre las zonas muestreadas, encontrándose valores de 50,1, 409,4 y 1499,0 tabánidos por trampa y por día para los casos de Guidiguis, Goulfey y Madiako, respectivamente. Los tabánidos resultaron más abundantes en los campamentos en comparación a los pastos y puntos de agua. Atylotus agrestis parece ser el principal vector mecánico potencial de los tripanosomas en la región bajo estudio.

Palabras clave: ganado bovino, Atylotus agrestis, Tabanidae, tripanosomosis africana, vectores, Camerún 